READINESS OF MICRO, SMALL AND MEDIUM ENTERPRISES USING

INFORMATION TECHNOLOGY (STUDY IN SELAYAR DISTRICT)

\title{
READINESS OF MICRO, SMALL AND MEDIUM ENTERPRISES \\ USING INFORMATION TECHNOLOGY (STUDY IN SELAYAR DISTRICT)
}

\author{
Andi Firmansyah ${ }^{1)}$, Nurhidayah A Yani2 ${ }^{2 *}$, Grace T. Pontoh ${ }^{3)}$, Arifuddin ${ }^{4)}$ \\ 1, 2, 3,4 Faculty of Economics and Business, Hasanuddin University, Indonesia
}

\begin{abstract}
This study examines the readiness of Micro, Small and Medium Enterprises (MSME) in Selayar Regency in using Information Technology (IT). The population in this study are all employees or employees who work in the MSME sector in the Selayar Islands Regency. Sampling using purposive sampling technique. This research is a research with a quantitative approach. The data in this study were collected using a questionnaire, then analyzed using regression analysis with the help of the SPSS 20 program. The results showed that: (1) optimism had a positive and significant effect on perceptions of IT use in SMEs in Selayar Regency; (2) innovation has a positive and significant effect on the perception of the use of IT in MSMEs in Selayar Regency; (3) insecurity has a negative and significant effect on the perception of the use of IT in MSMEs in Selayar Regency; (4) discomfort has a positive and insignificant effect on the perception of the use of IT in MSMEs in Selayar Regency; and (5) Perception of use has a positive and significant effect on the intention to use IT in MSMEs in Selayar Regency.
\end{abstract}

Keywords: Information Technology, MSMEs, Selayar Islands Regency

\section{INTRODUCTION}

Economic development in Indonesia cannot be separated from the role of the object driving the national economy, one of which plays an important role in it is Micro, Small and Medium Enterprises (MSMEs). MSMEs have a strategic role in national economic development, because apart from playing a role in economic growth and employment, they also play a role in the distribution of development outcomes. This business is often neglected only because its production is small and has not been able to compete with other business units when MSMEs should be a private development that must be focused on (Kristyanti, 2012).

Kristiyanti (2012) MSMEs are a form of community small business whose establishment is based on a person's initiative. Most people think that MSMEs only benefit certain parties. In fact, MSMEs play a very important role in reducing the unemployment rate in Indonesia. MSMEs can absorb a lot of Indonesian workers who are still unemployed. SMEs can help process natural resources in each region. This contributes greatly to Indonesia's regional and state revenues.

The Making Indonesia 4.0 strategy launched by the Ministry of Industry as a road map for Indonesia's strategy to enter the Industrial Revolution 4.0 (a period of very rapid IT development) so that Indonesia can compete with other countries. One of the strategies in the Industrial Revolution 4.0 is the empowerment of MSMEs which are the drivers of economic sector development in every country, especially developing countries. (Widayani et al, 2020).

In 2019, the number of MSMEs recorded in South Sulawesi Province was 916,232 units, this number increased compared to data in 2010 of 751,802 units Meanwhile, the number of MSMEs in the Selayar Islands Regency is 2,015 based on 2020 data.

*Coressponding author. Email address: nurhidayah27081995@gmail.com 


\section{AFEBI Economic and Finance Review (AEFR) Volume 6, No 02 (2021)}

Widayani, etc (2020) The current high number of MSMEs has the potential to penetrate a wider market and lead to the development of a technology and informationi-based global economy (IT). However, various factors affect the readiness of these MSMEs in adopting IT. Supporting factors are optimism, knowledge and skills of MSME actors, while inhibiting factors are perceptions of insecurity and discomfort.

In previous research, it was stated that the optimism factor affected the ability of MSMEs to adopt IT. MSME actors with an optimistic attitude have good hopes for vthe progress of IT development to support the readiness of MSMEs to adopt IT. Next is the knowledge and skill factor of MSME actors which includes the level of mastery of technology, understanding of business management, financial management, production process skills, communication and promotion skills, which are proven to have a positive influence on MSME readiness to adopt IT. Furthermore, the factors that hinder the readiness of MSMEs in adopting IT, namely insecurity and discomfort. In previous studies, the insecurity factor associated with transaction security is still considered vulnerable if it is carried out in full through the use of IT. Another factor is discomfort associated with ease of use and completeness of IT features.

Based on the description above, research was conducted with the title: " Readiness to Utilize Information Technology in Micro, Small and Medium Enterprises in Selayar Islands Regency".

\section{LITERATURE STUDY}

\section{Theoretical basis}

Theory of Reasoned Action is the performance of individual behavior that has been determined to be determined by the intention of the action to be taken with the goal of joint behavior determined by individual attitudes and subjective norms. This theory links beliefs, attitudes, intentions, and behaviors. Attitudes influence behavior through a careful and reasoned decision-making process and their impact is limited to only three things; First, behavior is not largely determined by general attitudes but by specific attitudes toward something. Second, behavior is influenced not only by attitudes but also by subjective norms, namely our beliefs about what other people want us to do. Third, attitudes towards behavior and subjective norms form certain intentions or intentions to behave. The model is Theory of Reasoned Action shown in Figure 1 below.

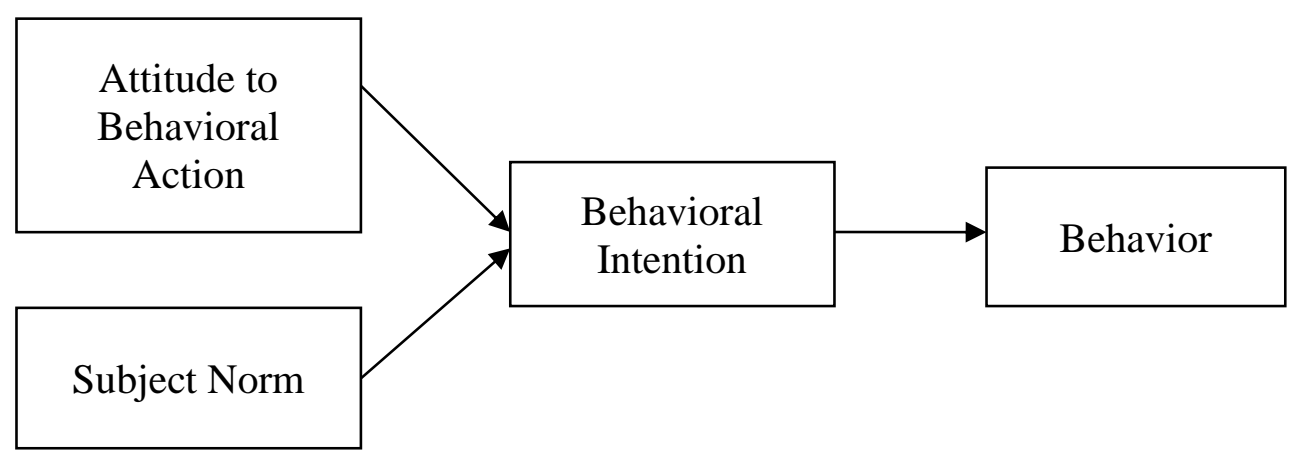

Figure 1. Theory of Reasoned Action Model

Technology Acceptance Model (TAM) was first introduced by Davis where TAM is an application developed from Theory of Reasoned Action (TRA) which is devoted to user acceptance. Based on the theory of Davis explains that the Technology Acceptance Model (TAM) is a model to predict and explain how technology users accept and use technology related to the user's work. One of the 


\section{READINESS OF MICRO, SMALL AND MEDIUM ENTERPRISES USING INFORMATION TECHNOLOGY (STUDY IN SELAYAR DISTRICT)}

factors that can influence is the user's perception of the usefulness and ease of use of information technology as an action in the context of information technology users so that the reason someone sees the benefits and ease of use makes that person's actions accept the use of information technology (Irawati et al, 2019).

This theory is generally developed into the characteristics of positive and negative values. The characteristics of the positive values expected in this study are optimism and innovation/skills of MSMEs, while the negative characteristics are insecurity and discomfort.

\section{Micro, Small and Medium Enterprises (MSMEs)}

According to the 1945 Constitution, it was later strengthened through Law no. 20 of 2008 concerning Micro, Small, and Medium Enterprises, MSMEs need to be empowered as an integral part of the people's economy that has a strategic position, role, and potential to realize a more balanced, developing, and just national economic structure.

Furthermore, the definition of MSMEs was made through Law No. 9 of 1999 , and due to the increasingly dynamic development situation, it was changed to Law No. 20 Article 1 of 2008 concerning Micro, Small and Medium Enterprises, the definition of MSMEs is as follows :

1. Micro Enterprises are productive businesses owned by individual or individual business entity that meets the criteria for Micro Business as regulated in this Law.

2. Small Business is a productive economic business that stands alone, which is carried out by individuals or business entities that are not subsidiaries or not branches of companies that are owned, controlled, or become part either directly or indirectly of Medium Enterprises or Large Businesses that meet the Business criteria. Small as referred to in this Law.

3. Medium Enterprises are productive economic businesses that stand alone, which are carried out by individuals or business entities that are not subsidiaries or branches of companies that are owned, controlled, or become part either directly or indirectly with Small Businesses or Large Businesses with total net assets or annual sales proceeds as regulated in this Law.

4. Large Business is a productive economic business carried out by a business entity with a net worth or annual sales proceeds greater than Medium Enterprises, which include state-owned or private national businesses, joint ventures, and foreign businesses conducting economic activities in Indonesia .

5. The Business World is Micro, Small, Medium, and Enterprises Largethat carry out economic activities in Indonesia and are domiciled in Indonesia .I

According to Article 6 of Law No. 20 of 2008 concerning the criteria for MSMEs in the form of capital, they are as follows: The

1. criteria for Micro Enterprises are as follows:

a. Have a net worth of at most $\mathrm{Rp} .50,000,000$. 00 (fifty million rupiahs) excluding land and buildings for business; or

b. Have annual sales of a maximum of Rp . 300, 000, 000 . 00 (three hundred million rupiahs ).

2. The criteria for Small businesses are as follows:

a. Have a net worth of more than Rp. 50,000,000.00 (fifty million rupiahs) up to a maximum of Rp. 500,000,000.00 (five hundred million rupiahs) excluding land and building for business; or

b. Have annual sales of more than Rp.300,000,000.00 (three hundred million rupiahs) up to a maximum of Rp.2,500,000,000.00 (two billion five hundred million rupiahs). 
3. The criteria for Medium Enterprises are as follows:

a. Have a net worth of more than Rp. 500,000,000.00 (five hundred million rupiahs) up to a maximum of Rp. 10,000,000.00 (ten billion rupiahs) excluding land and buildings for business premises; or

b. Have annual sales of more than IDR 2,500,000,000.00 (two billion five hundred million rupiahs) up to a maximum of IDR 50,000,000,000.00 (fifty billion rupiahs).

\section{Information Technology}

The term information technology (IT) became popular in the late 70s. In the past, the term information technology was commonly referred to as computer technology or electronic data processing. Information technology is defined as a technology for processing and disseminating data using hardware (hardware) and software (software), computers, communications, and digital electronics. Information Technology is a tool used to process data, such as processing, obtaining, compiling, storing, manipulating data in various ways to produce quality information, namely information that is relevant, accurate, and timely, which is used for personal, business, and government. IT is strategic information for decisionmaking. (Rahman, 2009). follows:

Aziz (2012) outlines the strategy of information systems and information technology as

a. Information Systems Strategy determines the information and system requirements for the business and its functional components. Information systems strategy describes what information systems are needed by the business to predict the future based on an analysis of the business, business environment, and business strategy. The goal is to determine the need for information systems and information technology applications that are closely related to business planning and problems. Requirements will change over time and requests must be continuously updated, reviewed, and prioritized based on business interests.

b. Information Technology Strategy determines how needs are based on priorities in information systems and information technology strategies that develop and operate current and future applications. This includes determining how the application will be generated and how technology and specialization resources will be obtained, used, managed, and managed to support the achievement of business needs.

\section{Research Hypothesis}

Hypothesis in this study is based on a causal relationship (influence) between the independent variable and the dependent variable shown. in Figure 2.

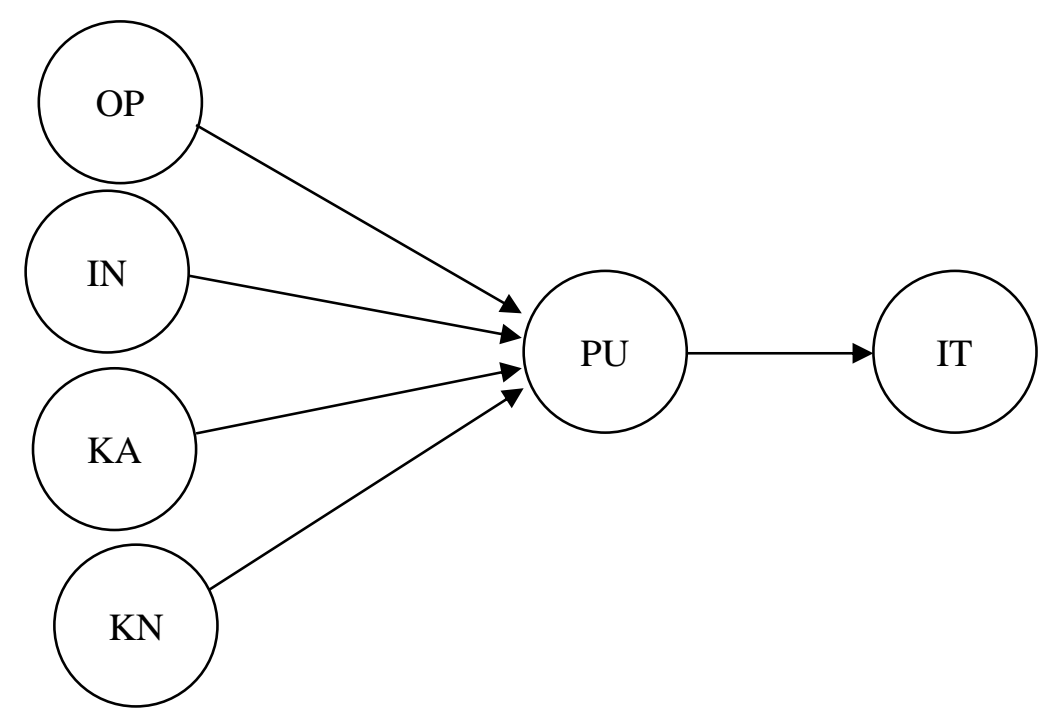




\section{READINESS OF MICRO, SMALL AND MEDIUM ENTERPRISES USING INFORMATION TECHNOLOGY (STUDY IN SELAYAR DISTRICT)}

Description:

Figure 2. Relationship Model between Research Variables

OP = Optimism

IN = Innovation

$\mathrm{KA}=$ Insecurity

$\mathrm{KN}=$ Inconvenience

$\mathrm{PU}=$ Perception of usefulness

IT = Intention to Use Information Technology

Based on Figure 2, the research hypothesis is structured as follows:

a. Effect of Optimism on perception of Usefulness

Optimisticleads to a more positive attitude and will help bring about a more positive attitude towards computers (Munger \& Loyd, 1989). Optimists will face things more actively than pessimists. This view is more effective in achieving positive results. It is inversely related to emotional distress, anxiety, and worry about bad experiences (Taylor \& Todd, 1995). Individuals who have high optimism do not consider the limitations that may occur. In their study of individual readiness for employees engaged in services, Walchuzh et al . ( 2007 ) found that employee optimism has a significant positive effect on perceived ease of use of information technology. Based on this statement, it is assumed that an optimist will perceive technology as easy to use because of the lack of concern about the possibility of negative results.

H1: Optimism has a positive and significant effect on perceived usefulness.

b. Influence of Innovation on Perceived Usefulness

Innovation is considered a trait that is not influenced by environmental or internal variables (Agarwal \& Prasad, 1997 ). Innovators rely less on subjective evaluations of others in the social environment about the consequences of adopting innovations (Rogers, 1995 ). Someone with a high PIIT (Personal Innovativeness in Technology Information ) will have a positive perception of technology. PIIT is a person's desire to try a variety of new information technologies ( Midgley and Dowling, 1978 ). Karahanna, Straub, and Chervany ( 1999 ) show that the more innovative a person is, the less complex he or she will have a set of beliefs about new technologies. Someone innovative will feel technology is something easy. This argument is supported by the findings of the study conducted by Walchuzh et al. (2007) which states that a person's innovation has a significant positive effect on perceived ease of use .

$\mathrm{H} 2$ : Innovation has a positive and significant effect on perceived usefulness.

c. Effect of Insecurity on Perception of Usefulness An

The obstacle for individuals to accept technology is the consideration of security and privacy issues because it can cause anxiety in accepting new technology. Someone who feels insecure will reduce his intention to use a certain technology (Walczuch et. al., 2007). These concerns raise individual skepticism towards technology and feelings of insecurity about technology will reduce the perception of ease of using technology. In their study of individual readiness for the technology of employees engaged in services, Walchuzh et al. (2007) found that employees' insecurity about technology has a significant negative effect on perceived ease of use of the technology.

H3: Insecurity has a negative and significant effect on perceived usefulness.

d. Influence of Discomfort on Perception of Usefulness

Individuals who have a feeling of discomfort in using technology will perceive technology in a more complex manner. These perceptions encourage individuals to 


\section{AFEBI Economic and Finance Review (AEFR) \\ Volume 6, No 02 (2021)}

perceive that technology is less easy or difficult to use. In certain contexts, individuals with a high level of discomfort prefer technology with a simpler standard model (Parasuraman, 2000). Empirical studies of Walczuch et al. (2007) found that employee discomfort harms perceived ease of use.

H4: Discomfort has a significant and negative effect on perceived usefulness.

e. The Effect of Perceived Usefulness on IT Use Intentions

Perceived ease of use and perceived usefulness are predictors of IT usage intentions (Davis et al., 1989; Igbaria et al., 1997; Chau and Hu, 2002). Individuals will intend to use IT when they judge that IT is useful and easy to use. Based on the Theory of Reasoned Action, individual behavior is determined by intentions. While intentions are determined by subjective norms (perceptions).

H5: Perceived usefulness has a positive and significant effect on IT Use Intentions.

\section{RESEARCH METHODOLOGY}

The study was conducted in the Selayar Islands Regency, South Sulawesi. This location was chosen because of the consideration that both the data and information needed are easy to obtain and relevant to the subject matter that is the main object of research. This research is expected to last for approximately one month, from October to September 2020.

The population in this study are all employees or employees who work in the MSME sector in the Selayar Islands Regency. Sampling in this study using the purposive sampling technique. Purposive sampling is a non-random sampling technique, or a sampling technique by specifying specific characteristics that are following the research objectives. The sample in this study acted as respondents who filled out the research questionnaire. The selected sample criteria are (1) MSME owners ; ( 2 ) MSME managers; and ( 3 ) MSMEs that have been or are currently using Information Technology ( IT ). The number of samples in this study was 50 people .

The data collected in this study used a questionnaire technique. Questionnaires were used to collect data on research variables, namely: optimism (X1), innovation (X2), security (X3), discomfort (X4), perception of use (Y1), and intention to use Information Technology (Y2). Questionnaires were distributed using google forms.

The data analysis technique used in this study consisted of descriptive analysis and regression analysis. The descriptive analysis uses descriptive statistics which include: minimum score, maximum score, range, mean, and standard deviation. Regression analysis aims to test the research hypothesis. Before the multiple linear regression analysis, the analysis prerequisite test was carried out which included the validity test, reliability test, normality test, multicollinearity test, and heteroscedasticity test.

\section{RESULTS AND DISCUSSION}

\section{Characteristics of Respondents}

This research was conducted by distributing questionnaires to 50 respondents who are MSME owners and managers who have been and are currently using IT in Selayar District. The following will describe the characteristics of the respondents.

Table 1. Characteristics of Respondents

\begin{tabular}{clcc}
\hline No. & \multicolumn{1}{c}{ Characteristics } & Frequency & Percentage $(\%)$ \\
\hline 1. & Age: & & \\
& $<25$ years & 35 & 70.00 \\
25 years & 15 & 30.00 \\
& Total & $\mathbf{5 0}$ & $\mathbf{1 0 0 . 0 0}$
\end{tabular}

2. Gender: 


\section{READINESS OF MICRO, SMALL AND MEDIUM ENTERPRISES USING INFORMATION TECHNOLOGY (STUDY IN SELAYAR DISTRICT)}

Male

Total

3. Education:

High School

D3

S1

Total

4. Position:

Manager

Own

Total

5. Asset Value:

$<50$ million

50 million - 500 million

Total
18

32

50

15

4

31

50

48

50

36.00

64.00

100.00

30.00

8.00

62.00

100.00

96.00

100.00

94.00

6.00

50

100.00

Source: primary data processed, 2021

From table 1 , it appears that by age, the research respondents are dominated by age $<25$ years $(70.0 \%)$. By gender, it is known that there are more female respondents $(64.0 \%)$. In terms of education, most of the research respondents came from an undergraduate education background $(62.0 \%)$. In addition, it is known that most of the research respondents are MSME owners (96.0\%). Furthermore, based on asset value, most of the respondents are MSMEs with an asset value of $<59$ million (94.0\%).

Test Validity and Reliability

Table 2 Test Validity

\begin{tabular}{|c|c|c|c|}
\hline Variable & Question & rcount $>$ rtable & Description \\
\hline Optimism (X1) & 1 & $0.814>0.235$ & Valid \\
\cline { 2 - 4 } & 2 & $0.880>0.235$ & Valid \\
\cline { 2 - 4 } & 3 & $0.850>0.235$ & Valid \\
\cline { 2 - 4 } & 4 & $0.836>0.235$ & Valid \\
\hline Innovation (X2) & 1 & $0.845>0.235$ & Valid \\
\cline { 2 - 4 } & 2 & $0.782>0.235$ & Valid \\
\cline { 2 - 4 } & 3 & $0.812>0.235$ & Valid \\
\cline { 2 - 4 } & 4 & $0.824>0.235$ & Valid \\
\cline { 2 - 4 } & 5 & $0.655>0.235$ & Valid \\
\hline Insecurity (X3) & 1 & $0.895>0.235$ & Valid \\
\cline { 2 - 4 } & 2 & $0.873>0.235$ & Valid \\
\hline Inconvenience (X4) & 3 & $0.850>0.235$ & Valid \\
\cline { 2 - 4 } & 1 & $0.872>0.235$ & Valid \\
\cline { 2 - 4 } & 2 & $0.874>0.235$ & Valid \\
\hline Perception of & 1 & $0.921>0.235$ & Valid \\
Usefulness (Y1) & & & Valid \\
\cline { 2 - 4 } & 2 & $0.782>0.235$ & Valid \\
\cline { 2 - 4 } & 3 & $0.778>0.235$ & Valid \\
\hline
\end{tabular}


AFEBI Economic and Finance Review (AEFR)

Volume 6, No 02 (2021)

\begin{tabular}{|l|c|c|c|}
\cline { 2 - 4 } & 4 & $0.845>0.235$ & Valid \\
\hline Intention to Use IT (Y2) & 1 & $0.907>0.235$ & Valid \\
\cline { 2 - 4 } & 2 & $0.655>0.235$ & Valid \\
\cline { 2 - 4 } & 3 & $0.653>0.235$ & Valid \\
\cline { 2 - 4 } & 4 & $0.863>0.235$ & Valid \\
\hline
\end{tabular}

Source: Primary data processed, 2021

The results of the validity test show that all the question items in the questionnaire are valid and can be used as research measuring tools. This is evidenced by the value of Corrected Item - Total $>0.235$.

Table 3 Reliability Test of

\begin{tabular}{lcc}
\hline \multicolumn{1}{c}{ Variables } & Alpha Coefficient & Information \\
\hline Optimism (X1) & 0.866 & Good \\
Innovation (X2) & 0.841 & Good \\
Insecurity (X3) & 0.842 & Good \\
Discomfort (X4) & 0.863 & Good \\
Perception of Use (Y1) & 0.851 & Good \\
Intention to Use IT (Y2) & 0.779 & Enough \\
\hline
\end{tabular}

Source: Primary data processed, 2021

Based on the results of reliability testing, it shows that all the variables used as instruments in the study are reliable and can be used as a data collection tool. So based on the results of the reliability test above, it shows that the instrument has a high level of reliability, this is evidenced by thecoefficient value alpha $>0.60$, so the measurement results that will be obtained can be trusted.

\section{Classic assumption test}
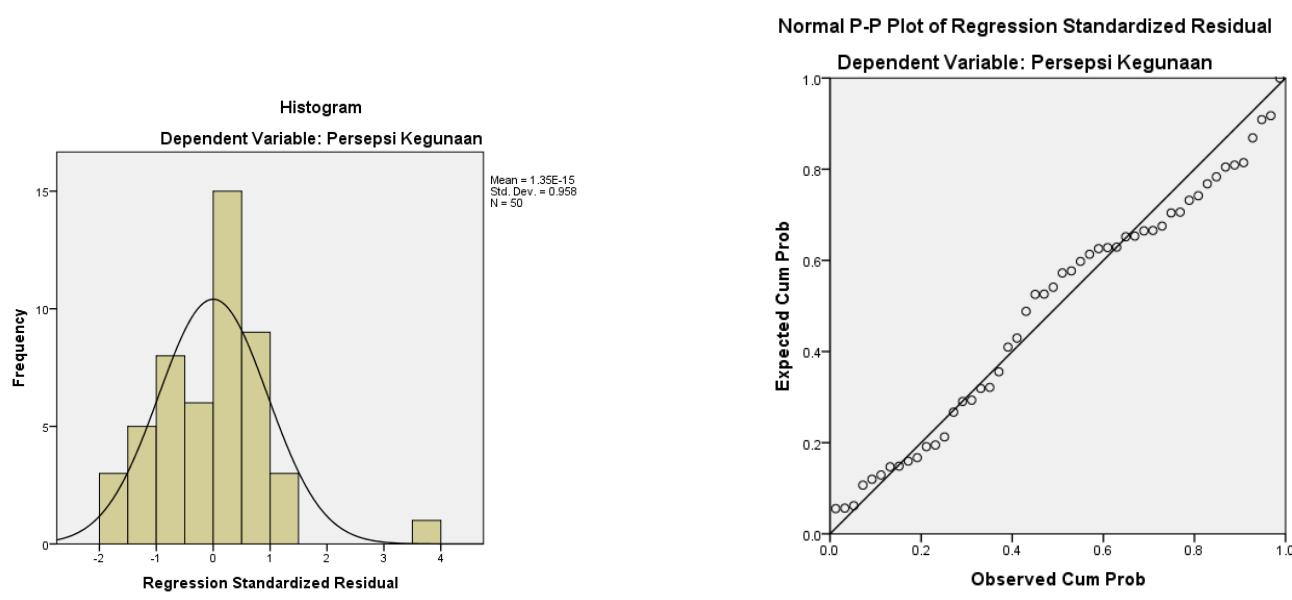

(a) Histogram Graph (b) Normal P-Plot

Graph Figure 3. Normality Test Results

In Figure 3(a) it appears that the distribution pattern is close to the normal curve and in Figure 3(b) it appears that the data is spread around the diagonal line. Thus it can be concluded that the assumption of normality has been met. 


\section{READINESS OF MICRO, SMALL AND MEDIUM ENTERPRISES USING INFORMATION TECHNOLOGY (STUDY IN SELAYAR DISTRICT)}

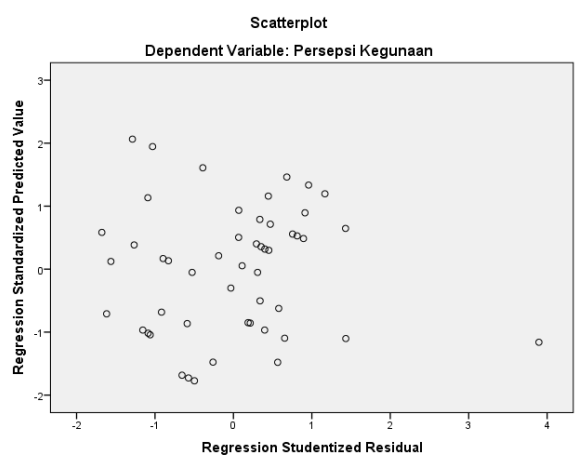

Figure 4. Graph Scatterplot

In Figure 4 it can be seen that the points are spread out and do not form a certain clear pattern, and are spread both above and below the number 0 on the $\mathrm{Y}$ axis, this means that there is no heteroscedasticity in the regression model, so this model is feasible to use. to perform multiple linear regression.

Table 4 Multicollinearity Test for

\begin{tabular}{lcc}
\hline \multicolumn{1}{c}{ Variables } & VIF & Information \\
\hline Optimism (X1) & 1,805 & NoMulticollinearity \\
Innovation(X2) & 1,903 & NoMulticollinearity \\
Insecurity (X3) & 1.556 & No Multicollinearity \\
Discomfort (X4) & 1.704 & No Multicollinearity \\
Perception of Use (Y1) & 1,000 & No Multicollinearity \\
\hline
\end{tabular}

Source: primary data processed, 2021

Based on the table above, it can be concluded that the regression model for the independent variables proposed by the researcher to be studied is free from multicollinearity. This can be proven by looking at the table above which shows the VIF value of each independent variable $<10$ and can be used, both to determine the effect of optimism, innovation, insecurity, and discomfort on perceived use and to determine the effect of perceived use on IT usage intentions.

\section{Hypothesis Testing}

Table 5 Coefficients 1

\begin{tabular}{|c|c|c|c|c|c|c|c|}
\hline \multirow[t]{2}{*}{ Model } & \multicolumn{2}{|c|}{$\begin{array}{c}\text { Unstandardized } \\
\text { Coefficients }\end{array}$} & \multirow{2}{*}{$\begin{array}{c}\begin{array}{c}\text { Standardized } \\
\text { Coefficients }\end{array} \\
\text { Beta }\end{array}$} & \multirow[t]{2}{*}{$\mathrm{t}$} & \multirow[t]{2}{*}{ Sig. } & \multicolumn{2}{|c|}{$\begin{array}{l}\text { Collinearity } \\
\text { Statistics }\end{array}$} \\
\hline & $B$ & Std. Error & & & & Tolerance & VIF \\
\hline .915 .373 .018 & & & & 2,452 & $\begin{array}{l}\text { (Con } \\
\text { stant }\end{array}$ & & \\
\hline optimism & $\begin{array}{r}.083 \\
.537 .0 \\
00 \\
.554\end{array}$ & & & 5,238 & & .437 & 1,805 \\
\hline innovation & $\begin{array}{r}.091 \\
.387 .5 \\
25\end{array}$ & & & 3,672 & .001 & 336 & 1,903 \\
\hline Insecurity & -.114 & .065 & -.168 & -1.764 & .045 & .643 & 1,556 \\
\hline Discomfort & .053 & .075 & .070 & .698 & .489 & .587 & 1,704 \\
\hline
\end{tabular}

Source: SPSS Output, 2021

Based ontable Coefficients above, the regression equation is known as follows:

$$
Y_{1}=0.915+0.437 X_{1}+0.336 X_{2}-0.114 X_{3}+0.053 X_{4}
$$


The multiple linear regression equations above can be explained in detail:
a. Constant $(\alpha)$
Constant of 0.915 . This means that if there is no change in the variables of optimism, innovation, insecurity, and discomfort, the perception of use is 0.915 .

\section{b. Optimism (X1)}

The regression coefficient value for optimism is 0.437 . In this study, it can be stated that optimism has a positive effect on perceptions of use. Every increase in optimism will have an impact on increasing perceptions of use by 0.437 . Meanwhile, it is also known that the value of Sig. optimism is 0.000 , and this value is smaller than the degree of error $(\alpha=0.05) \quad(0.000<0.05)$. This means that optimism has a significant effect on user perceptions. Thus, the first hypothesis (H1) proposed in this study is accepted.

\section{c. Innovation (X2)}

The regression coefficient value for optimism is 0.336 . In this study, it can be stated that innovation has a positive effect on perceptions of use. Each increase in innovation will have an impact on increasing perceptions of use by 0.336 . Meanwhile, it is also known that the value of Sig. innovation is 0.001 , and the value is smaller than the degree of error $(\alpha=0.05)(0.001<0.05)$. This means that innovation has a significant effect on perceptions of use. Thus, the second hypothesis (H2) proposed in this study is accepted.

\section{d. Insecurity (X3)}

The regression coefficient value for optimism is -0.114 . In this study, it can be stated that insecurity harms perceptions of use. Each increase in insecurity will have an impact on decreasing the perception of use by 0.114 . Meanwhile, it is also known that the value of Sig. optimism is 0.045 , and this value is smaller than the degree of error $(\alpha=0.05)$ $(0.045<0.05)$. This means that insecurity has a significant effect on perceptions of use. Thus, the third hypothesis (H3) proposed in this study is accepted.

\section{e. Discomfort (X4)}

The regression coefficient for optimism is 0.053 . In this study, it can be stated that discomfort has a positive effect on perceptions of use. Each increase in discomfort will have an impact on increasing the perception of use by 0.053 . Meanwhile, it is also known that the value of Sig. discomfort is 0.489 , and the value is greater than the degree of error $(\alpha=0.05)(0.489>0.05)$. This means that discomfort does not significantly affect the perception of use. Thus, the fourth hypothesis (H4) proposed in this study was rejected.

Table 6 Coefficients 2

\begin{tabular}{|c|c|c|c|c|c|c|c|}
\hline Model & $\begin{array}{r}\text { Unstal } \\
\text { Coe }\end{array}$ & $\begin{array}{l}\text { dardized } \\
\text { ficients }\end{array}$ & $\begin{array}{l}\text { Standardized } \\
\text { Coefficients }\end{array}$ & $\mathrm{t}$ & Sig. & \multicolumn{2}{|c|}{ Collinearity Statistics } \\
\hline & $\mathrm{B}$ & Std. Error & Beta & & & Tolerance & VIF \\
\hline .468 & 1,433 & (Constant) & & 3,061 & .004 & & \\
\hline $\begin{array}{l}1 \text { Perceived } \\
\text { Usefulness }\end{array}$ & $\begin{array}{r}.144 \\
.504 .0 \\
00\end{array}$ & & & 4,039 & .582 & 1,000 & 1,000 \\
\hline
\end{tabular}

Source: SPSS output, 2021

According to the table Coefficients above, the regression equation is known as follows:

$$
\mathbf{Y}_{2}=\mathbf{1 . 4 3 3}+\mathbf{0 , 5 8 2} \mathbf{Y}_{1}
$$

The multiple linear regression equations above can be explained in detail:

\section{a. Constant $(\alpha)$}

Constant of 0.143 . This means that if there is no change in the perceived use variable, then the intention to use IT is 1.433 .

b. Perceived Use (Y1) 


\section{READINESS OF MICRO, SMALL AND MEDIUM ENTERPRISES USING INFORMATION TECHNOLOGY (STUDY IN SELAYAR DISTRICT)}

The regression coefficient value for perceived use is 0.582 . In this study, it can be stated that the perception of use has a positive effect on the intention to use IT. Each increase in perception of use will have an impact on increasing the intention to use IT by 0.582 . Meanwhile, it is also known that the value of Sig. perception of use is 0.000 , and this value is smaller than the degree of error $(\alpha=0.05)(0.000<0.05)$. This means that the perception of use has a significant effect on the intention to use IT. Thus, the fifth hypothesis (H5) proposed in this study is accepted.

Table 7 Determination Coefficient Test Results 1

\begin{tabular}{lrrrr}
\hline Model & $\mathrm{R}$ & $\mathrm{R}$ Square & $\begin{array}{c}\text { Adjusted R } \\
\text { Square }\end{array}$ & $\begin{array}{c}\text { Std. The error of } \\
\text { the Estimate }\end{array}$ \\
\hline 1 & $.859^{\mathrm{a}}$ & $\mathbf{. 7 3 8}$ & .714 & .35384 \\
\hline
\end{tabular}

Source: SPSS Output, 2021

Based on the table above, shows that the coefficient of determination (R-Square) is 0.738 or $73.8 \%$. This means that the variable use of perception can be explained by the variables of optimism, innovation, insecurity, and discomfort by $73.8 \%$ and the remaining $26.2 \%$, explained by other variables outside the variables in the research model.

\begin{tabular}{lrrrr}
\multicolumn{4}{c}{ Table 8 Coefficient of Determination Test Results 2 } \\
\hline Model & R & R Square & $\begin{array}{c}\text { Adjusted R } \\
\text { Square }\end{array}$ & $\begin{array}{c}\text { Std. Error of the } \\
\text { Estimate }\end{array}$ \\
\hline 1 & $.504^{\mathrm{A}}$ & $\mathbf{. 2 3 8}$ & & .254 \\
\hline
\end{tabular}

Source: SPSS output, 2021

Based on the table above, shows that the coefficient of determination(R-Square) of 0.254 or $25.4 \%$. This means that the variable of intention to use IT can be explained by the variable of perception of use by $25.4 \%$ and the rest is $74.6 \%$, explained by other variables outside the variables in the research model.

Coefficient determination ( $R$-Square) is used to measure how much endogenous variables are influenced by other variables. Chin (in Ghozali, 2016), the outcome of $\mathrm{R}^{2}$ of 0.67 upwards for the dependent variable in the structural model indicates the influence of the independent variables (affecting) variable dependent (influenced) included in both categories. Meanwhile, if the result is $0.33-0.67$ then it is included in the medium category, and if the result is $0.19-0.33$ then it is included in the weak category. Thus, this research model can be categorized as good and weak.

\section{Discussion}

\section{The Effect of Optimism on Perception of Use}

The results of the study found that optimism had a positive and significant effect on perceived usage. This means that optimism is a supporting factor as well as a determining factor in the perception of MSME actors in using IT. The results of this study support the theory Technology Acceptance Model (TAM)where MSME actors accept information technology because of its usefulness and convenience.

The results showed that MSMEs in Selayar District had good optimism and formed their perception of the use of IT. Individuals who have high optimism do not consider the limitations that may occur. In their study of individual readiness for employees engaged in services, Walchuzh et al. (2007) found that employee optimism has a significant positive effect on perceived ease of use of information technology.

\section{Influence of Innovation on Perception of Use}

The results of the study found that innovation has a positive and significant effect on perceived use. This means that innovation is a supporting factor as well as a determining 


\section{AFEBI Economic and Finance Review (AEFR)}

Volume 6, No 02 (2021)

factor for the perception of MSME actors in using IT. The results of this study support the theory Technology Acceptance Model (TAM)where MSME actors accept information technology because of its usefulness and convenience. Innovative MSME actors will have a good acceptance of information technology.

The results of this study indicate that MSMEs in Selayar Regency have good innovation and this shapes their perception of the use of IT. Someone with a high PIIT (Personal Innovativeness in Technology Information) will have a positive perception of technology. PIIT is a person's desire to try a variety of new information technologies (Midgley and Dowling, 1978). Karahanna, Straub, and Chervany (1999) show that the more innovative a person is, the less complex a person's set of beliefs about new technologies will be. Someone innovative will feel technology is something easy. This argument is supported by the findings of the study conducted by Walchuzh et al. (2007) which states that a person's innovation has a significant positive effect on perceived ease of use.

\section{The Effect of Insecurity Against Perceived Use}

The results of the study found that insecurity has a negative and significant effect on perceptions of use. This means that insecurity is an inhibiting factor as well as a determining factor in the perception of MSME actors in using IT. The results of this study indicate that SMEs in Selayar Regency consider the insecurity factor in shaping their perception of the use of IT.

The results of this study are in line with the opinion of Walchuzh et al. (2007), that these concerns raise individual skepticism towards technology and feelings of insecurity towards technology will reduce the perception of ease of using technology. In his study of individual readiness for technology employees engaged in services, found that employee insecurity about technology has a significant negative effect on perceived ease of use of the technology.

\section{The Effect of Discomfort on Perception of Use}

The results of the study found that discomfort had a positive and insignificant effect on perceptions of use. This means that discomfort is a supporting factor but not a determining factor in the perception of MSME actors in using IT. The results of this study do not support the Technology Acceptance Model (TAM) theory where MSME actors accept information technology because of its usefulness and convenience.

The results of this study indicate that SMEs in Selayar Regency does not consider the inconvenience factor in shaping their perception of the use of IT. The inconvenience of using IT in conducting business activities is not the main factor for SMEs in Selayar Regency. This is because MSME actors have no other choice but to use IT, even though they do not feel comfortable.

\section{The Effect of Perception of Use on Intention to Use IT}

The results of the study found that the perception of use has a positive and significant effect on the intention to use IT. This means that the perception of use is a supporting factor as well as a determining factor whether or not MSME actors intend to use IT.Hal ini menunjukkan bahwa persepsi pelaku UMKM di Kabupaten Selayar menentukan niat mereka dalam menggunakan TI.

The results of this study support the Theory of Reasoned Action in which individual behavior is determined by intentions. While intentions are determined by subjective norms (perceptions). Perceived use is a predictor of IT use intention (Davis et al., 1989; Igbaria et al., 1997; Chau and $\mathrm{Hu}, 2002$ ). Individuals will intend to use IT when they judge that IT is useful and easy to use.

\section{CONCLUSION}

Based on the results of the research and discussion, the conclusions of this study are: (1) optimism has a positive and significant effect on the perception of the use of IT in SMEs 


\section{READINESS OF MICRO, SMALL AND MEDIUM ENTERPRISES USING INFORMATION TECHNOLOGY (STUDY IN SELAYAR DISTRICT)}

in Selayar Regency; (2) innovation has a positive and significant effect on the perception of the use of IT in MSMEs in Selayar Regency; (3) insecurity has a negative and significant effect on the perception of the use of IT in MSMEs in Selayar Regency; (4) discomfort has a positive and insignificant effect on the perception of the use of IT in MSMEs in Selayar Regency; and (5) Perception of use has a positive and significant effect on the intention to use IT in MSMEs in Selayar Regency.

Based on the conclusions of the study, the research implications are: (1) the perception of the use of IT depends on the factors of optimism, innovation, and insecurity; (2) discomfort is not a determinant of perceived IT use; (3) the perception of the use of IT is a factor forming the intention to use IT; (4) MSME actors need to maintain a positive perception in understanding IT; and (3) the Department of Cooperatives and SMEs in Selayar Regency to continue to disseminate information on the use of IT to foster public interest in MSMEs.

\section{Reference}

Achjari, Didi, et al. 2011. Kesiapan Usaha Mikro, Kecil dan Menengah industri Kreatif untuk Mengadopsi Teknologi informasi. Fakultas Ekonomika dan Bisnis Universitas Gajah Mada: Yogyakarta. P.153-154

FD, Davis, A. 1986. Technology acceptance model for empirically testing new end-user information systems; Theory and Result, Unpublished Ph.D. Dissertation Sloan: Sloan School of Management, Massachusetts Institute of Technology (MIT).

Irawati, Tri et al. 2019. Penggunaan Metode Technology Acceptance Model (TAM) Dalam Analisis Sistem Informasi Alista (Application Of Logistic And Supply Telkom Akses). STMIK Sinar Nusantara Surakarta.

Karahanna, E., Straub, DW, \& Chervany, NL (1999). Information technology adoption across time: A cross-sectional comparison of pre-adoption and postadoption beliefs. MIS Quarterly, 183- 213.

Kristiyanti, Mariana. 2012. Peran Strategis Usaha Kecil Menengah (UKM) dalam Pembangunan Nasional. Fakultas Ekonomi Universitas iAKI. P.63-64. Law of the Republic of Indonesia Number 20 of 2008 concerning Micro, Small and Medium Enterprises

Rahmana, Arief. 2009. Peranan Teknologi Informasi Dalam Peningkatan Daya Saing Usaha Kecil Menengah. Fakultas Teknik,Universitas Widyatama: Bandung. P. 3

Scheier, MF, \& Carver, CS (1987). Dispositional optimism and physical wellbeing: The influence of generalized outcome expectancies on health. Journal of Personality and Social Psychology 55, 169-210.

Suci, YR. 2017. Perkembangan UMKM (Usaha Mikro Kecil dan Menengah) di Indonesia.Sekolah Tinggi Ilmu Ekonomi Balikpapan. P. 54-55

Walczuch, R., Lemmink, J., \& Streukens, S. (2007). The effect of service employees' technology readiness on technology acceptance. Information \& Management, 44(2), 206-215

Widayani, et al. 2020. inCompetence and readiness of small and medium industries against of industrial revolution 4.0. Department of Business Administration, Faculty of Administrative Science, University of Brawijaya: Poor. P.1-3 